DOI: https://doi.org/10.32839/2304-5809/2019-10-74-59

UDC 378.014.5-027.543(73)«20»

\author{
Smolikevych Nadiya \\ Ivan Franko National University of Lviv \\ Chernozubova Nadiya \\ Ukrainian Academy of Printing
}

\title{
INTERNATIONALISATION FEATURES OF US HIGHER EDUCATION
}

Summary. The article proposes the analysis of the process of internationalization of higher education in the United States. The terms "multicultural education", "globalization", and "internationalization" in the field of higher education have been explained. The dominant features of internationalization of US higher education and the positive aspects have been presented. The basic principles of its internationalization have been revealed too. Attention has also been paid to pedagogy for civil society, which supports the process of internationalization and is widespread in the USA. The main strategies for internationalization of higher education have been outlined. Internationalized programs have been described as a major element of higher education internationalization. The general requirements for teachers and students have been explored and a model of comprehensive internationalization of US higher education has been developed.

Keywords: internationalization, higher education, student mobility, educational program, internationalization strategies, USA.

Смолікевич H.P.

Львівський національний університет імені Івана Франка

Чернозубова Н.А.

Українська академія друкарства

\section{ОСОБЛИВОСТІ ІНТЕРНАЦІОНАЛІЗАЦІЇ ВИЩОЇ ОСВІТИ США}

\begin{abstract}
Анотація. Стаття аналізуе процес інтернаціоналізації вищої освіти у США. Подано тлумачення термінів «мультикультурна освіта», «глобалізація» та «інтернаціоналізація» у сфері вищої освіти. Охарактеризовано інтернаціоналізацію вищої освіти США як процес інтеграції міжнародних і культурних аспектів у навчанні, дослідженнях і діяльності установи та її головні позитивні моменти, а саме: створення єдиного світового освітнього простору завдяки міжнародній співпраці та інтеграції, мобільність, демократія, диверситивність та ін.. Розкрито основні їі принципи, серед яких виокремлено підпорядкованість міжнародної діяльності насамперед зовнішній політиці та принцип мультикультуралізму з акцентом на глобальній та міжкультурній обізнаності у навчальних цілях, глобалізації освітніх програм і програм навчання за кордоном. Такі освітні програми передбачають створення для студентів міжнародної перспективи і глобальної компетентності, а принцип мультикультуралізму забезпечує толерантність до расових, етнічних, релігійних та світоглядних відмінностей серед учасників освітнього процесу. Звернено увагу на педагогіку для громадянського суспільства, яка підтримує процес інтернаціоналізації і є поширеною у США. Досліджено головні стратегії інтернаціоналізації вищої освіти стратегія: партнерство між з метою розвитку глобальній мобільності здобувачів вищої освіти та академічного складу, стратегія висококваліфікованої міграції для залучення кваліфікованих спеціалістів та стратегія отримання доходу, оскільки іноземні студенти сплачують значно більше за навчання, ніж місцеві у США. Поширеною практикою США у сфрері міжнародної діяльності є навчання студентів в іншій країні упродовж семестру, навчального року чи у літній період. Успішність інтернаціоналізації вищої освіти у США підтверджується зростаючою кількістю іноземних студентів, які бажають отримати престижний диплом чи міжнародний досвід навчання на певний період за програмою. Розглянуто інтернаціоналізовані програми як головний елемент сучасної вищої освіти. Узагальнено ключові вимоги до викладачів і студентів та розроблено модель комплексної інтернаціоналізації вищої освіти США.
\end{abstract}

Ключові слова: інтернаціоналізація, вища освіта, мобільність студентів, освітня програма, стратегії інтернаціоналізації, США.

Droblem statement. In recent years, there

1 has been an enhanced internationalization process of US higher education and the formation of a more accessible continuing education system, becoming a form of general education for the population. This trend is driven by the inevitable result of a knowledge-based economy. The past decade has seen the rapid development of higher educational institutions in strengthening international relations and educational internationalization around the world, which leads to diversity, expansion, and privatization $[4 ; 7]$.

Extensive research has shown that internationalization of education is characterized by the formation of a single world educational space through in- ternational cooperation and integration of advanced countries in the development of common standards of education, valid diplomas, the possibility of global student mobility and teachers' multicultural development. It envisages the development of intercultural understanding and tolerance in a multicultural educational environment, the promotion of universal democratic values, the protection of rights and freedoms of each person. Higher education internationalization has been studied to operate in terms, such as global civil society, global mobility, democracy, diversification, multiculturalism, bilingualism and citizenship. The process of internationalization is supported by US-based civil society pedagogy, based on methodological tools, such as case studies, 
discourse analysis, and reflection; and empirical research [2, pp. VI-VII].

Previous research has established that the internationalization process promotes the development of multicultural education. Huletska (2008) defines multicultural education as part of professional education aimed at assimilating cultural and educational values based on knowledge of peculiarities of the own ethno-cultural group, as well as the interaction of all cultures on the principles of understanding, tolerance, dialogue and pluralism, which prevents confrontation, discrimination, and racism.

An analysis of recent researches and publications has shown that American authors devoted their work to innovative topics of global pedagogy that reveal effective ways, tools for creating a civic community: Holm (2005), Nations Jonson (2005) considered the concepts of academic-community development, Brice (2005) - organization of civic discourse at lessons, Hill (2006), De Wit (2010) - principles of internationalization of higher education in the United States. Postman (1996) argued that the United States was a great experiment in exploring the possibility of creating a common democratic civil society by means of modern education, uniting people of different ethnic and racial backgrounds, based on a sense of shared unity and allowing broad freedom. Gallagher (2005) explored the role of education in the development of stable democratic politics. Holm (2005) revealed the essence of multicultural education, examined its main problems and mechanisms in the context of pedagogical education and scientific research. Koshmanova stated that multicultural education and cultural diversity were problems that all educators in the international education sphere should study and be acquainted with.

Altbach, Reisberg, and Rambley (2009) consedered globalization and internationalization as similar processes, but having some differences. Globalization is the context of economic and scientific tendencies that are the part of the 21 st century reality. At the same time, internationalization encompasses the policies and practices of the university to meet global academic trends. Motivation of internationalization involves commercial gain; knowledge acquisition and foreign language learning; improvement of educational programs with the content containing an international component, international activity, etc [10].

De Wit (2010) shares the view of Altbach \& Knight (Altbach \& Knight, 2007) that education internationalization at the higher educational institution level is a "process of integrating international and cultural aspects in the institution's teaching process, research and other activity", internationalization is changing the higher education establishment, but globalization is influencing the world of internationalization $[9 ; 13$, p. 8].

The key principles of higher education internationalization in the United States, according to Knight, are as follows: international activities in the United States are primarily governed by foreign policy and national security, the principle of multiculturalism, emphasis on global and intercultural awareness for educational purposes, internationalization of educational and training programs, It should be noted that internationalization of higher education in the Unit- ed States is not a strategic goal and can be described as fragmented activity [13, pp. 5-12].

Previously unsolved parts of the general problem. Having studied scientific and pedagogical sources on this topic, we have found out that a comprehensive study of various aspects of the internationalization process of higher education in the United States has not yet been completed.

The research objective. The aim of the article is to do a comprehensive thorough analysis of the internationalization process in US universities, and define the benefits of its implementation in the educational space.

The main body of the research. According to the global ranking of countries with the most favorable policy in the field of education internationalization, we consider the Global gauge as an interactive monitoring of state support for the higher education internationalization, expressed in the policies, national strategies and legislation basis of the countries. In the ranking of the 26 countries the United States ranks the $10^{\text {th }}$ one in 2016 [12].

Having examined the issues of higher education internationalization and international cooperation, we assert that it is implemented by the Government in the following areas, as providing a favorable environment for international mobility of students and academics, academic exchange and international university researches; ensuring the quality of educational standards and recognition of diplomas, educational programs implementation with an international component; free access to higher education [12].

Kuriy (2010) identifies such main strategies for internationalization higher education, as 1) mutual understanding strategy based on the global mobility of higher education applicants through exchange, scholarship and partnership programs between institutions; 2) a strategy of highly skilled youth migration, which involves targeted employment of foreigners in the country of destination in order to attract talented young people and scholars; 3 ) an income strategy as foreign students pay far more for tuition than local students [3].

We have found out that the Center for Internationalization Programs and Global Participation, Services and Resources has been established in the United States to support higher educational institutions in achieving comprehensive internationalization and preparing students for successful work in the face of growing globalization. The Center provides a thorough analysis of international educational programs and services to support the internationalization and engagement strategy of the institutions $[6 ; 8]$.

The Center for Internationalization and Global Engagement of the American Council on Education (CIGEACE) is helping universities and colleges to develop and support comprehensive, effective internationalization programs that enhance global participation of students and faculty. Effective internationalization requires comprehensive institutional support encompassing educational programs, research, educational staff's work, and proactive synergies between the institutions. In addition, the organization researches and analyzes global tendencies in higher education working with educational associations worldwide [8]. 
The Commission on Internationalization and Global Interaction is an important advisory body to the Center on internationalization initiatives and global priorities. The commission fulfills its functions by developing international education policy, conducting researches in the field of education internationalization, sponsoring programs for the promotion of education internationalization, and is the agency of the US higher education representation at the international level [8].

We state that the American Council on Education's Center for Internationalization and Global Liaison helps educational institutions develop and support comprehensive, effective internationalized programs that increase the global participation of students, faculty, and staff. Its activities promotes the idea that effective internationalization requires comprehensive cooperation between institutions, involves the development of educational programs, researches, the faculties' active strategies of interaction. The organization also monitors and analyzes global trends in higher [8].

It is important to consider the Center's Comprehensive Internationalization Model, which is a strategic, coordinated process that integrates policy, programs, and initiatives into colleges and universities (see fig. 1). Its activities include providing a roadmap for implementation of internationalization, forming focus groups, conducting interviews and open discussions on formulating priorities and solutions to students and faculty's problems. Employees are primarily responsible for internationalization results before the Director-General or the President of the internationalization program $[6 ; 8]$.

It has been explored that student mobility is seen as a major driving force in the process of internationalization of higher education: Orientation programs and numerous campus resources (Office of International Students (OIS), Office of International Programs (OIP), International Student Association (ISA)) help facilitate adaptation and provide students' effective learning and transferring the credits obtained. To further student mobility financial aid is received by students participating in study abroad programs approved by the US Department of State's Department of Education and Cultural Programs (e.g. Global UGRAD - Global Undergraduate Exchange Program) [5].

The importance and originality of this study are that it outlines general requirements for internationalized education: knowledge of a foreign language, and researches into global content with a strong focus on internationalized educational programs, technology, work on a collaborative project, cooperation with teachers and students abroad by holding online conferences, discussions, roundtables, etc. The teacher's activity is supported on campus too where seminars and advanced training programs help educators gain international competence and put it into practice. So, key guides in the preparation of future teachers are international experience and professional knowledge [8].

According to the research by the Institute of International Education (IIE), the United States has made a significant contribution to the process of globalization and internationalization of higher education through the international activities of a lot of public and private educational organizations, counseling centers activities, successful implementation of educational programs etc. For example, the US Department of State Bureau of Educational and Cultural Affairs promotes education internationalization through academic, cultural, sport, professional, and private exchanges. About 50,000 students participate in exchange programs annually, including the flagship Fulbright Program and the International Visitor Leadership Program. The Bureau also sponsors the Benjamin A. Gilman Scholarships for American students with financial needs, the Critical Language Scholarship Program and over 400 consulting centers of EducationUSA net around the world, which provide students who are going to study in the USA with the information [14].

One of the facts of US higher institutions' international activity in promoting the internationalization in the sphere of higher education is students' opportunity to study in another country during the semester, academic year or summer. They can also be enrolled in short-term language studying programs, internship or work-study programs. Popular countries among American students are Australia, United Kingdom, Costa Rica, Italy, and Spain. It should be noted that international exchange programs for teachers are also supported [17].

Research conclusions. The success of the United States in the field of higher education internationalization ensures the further growth of the number of international students who are willing to receive a diploma or international study experience for a certain period under the program, which has a significant positive impact on the economy of the country. Students from all over the world studying in the US also contribute to the development of American science and technology, conducting research, providing intercultural awareness and other international learning perspectives for American students, helping them be prepared for a global career and often create long-lasting business relationships, which leads to other economic benefits [15].

Having analyzed the internationalization dominant features of US higher, we can conclude that it occurs with varying intensity. Just as the internationalization process in different institutions is presented in the range from a set of uncoordinated international activities to a strategically c comprehensive internationalization model.

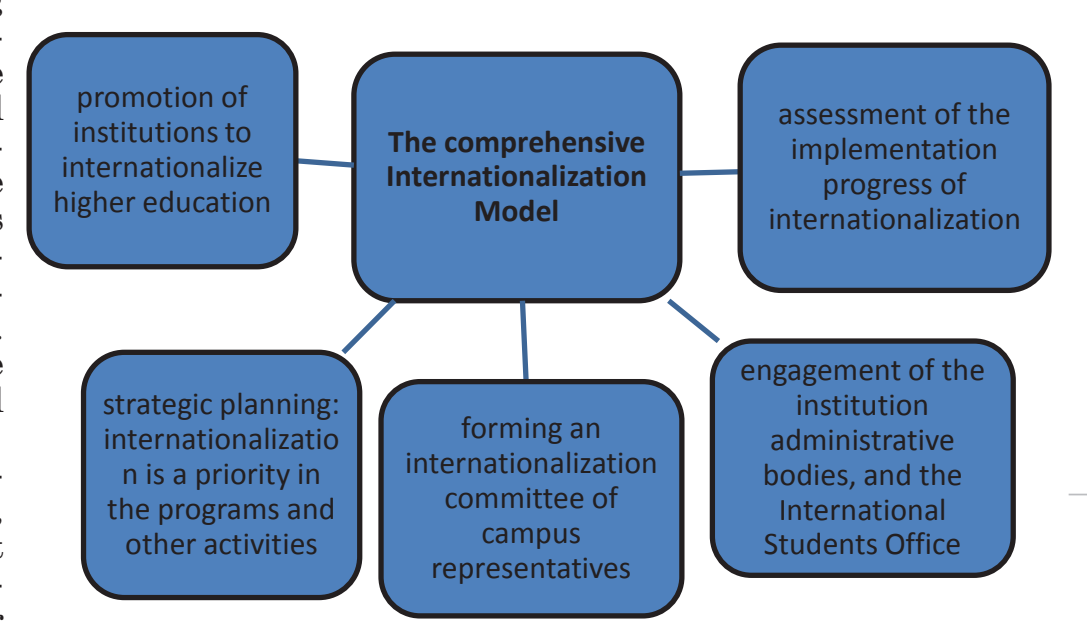

Fig. 1. The Comprehensive Internationalization Model 


\section{References:}

1. Huletska, Ya.H. (2008). Polikulturna osvita studentskoi molodi v universytetakh SSHA [Multicultural Education of Student Youth at US Universities]. (PHD Thesis: 13.00.01). Available at: http://www.lib.ua-ru.net/diss/cont/343289.html (accessed 11 January 2018).

2. Koshmanova, T., Brice, L., Holm, I., Nations Jonson, L., Ravchyna, T. \& Rao, Sh. (2005). Pedahohika dlia hromadianskoho suspilstva [Pedagogy for Civil Society] (ed. T.S. Koshmanova). Lviv : Publishing Center of Ivan Franko National University of Lviv.

3. Kurii, L.O. (2010). Internationalizatiia vyschoi osvity yak zasib formuvannia liudskoho potentsialu v konteksti mizhnarodnykh mihratsiynykh procesiv [Internationalization of higher education as a means of forming human potential in the context of international migration processes]. Ukraine's Development Strategy in the Global Environment: Proceedings of the IV International Scientific and Practical Conference. Simferopol : VitPrint, $269-273$.

4. Matvienko, O.V. \& Kudina, V.V. (Red.) (2013). Teoretychni pytannia kultury, osvity ta vykhovannia [Theoretical issues of culture, education and upbringing]. Collection of scientific works, 47. Kyiv : Ed. center of KNLU.

5. Smolikevych, N.R. (2015). Mobilnist inozemnykh studentiv u hlobalnomu osvitniomu prostori: perspektyvy ta vyklyky [Foreign Students' mobility in the global educational space: prospects and challenges]. Humanitarian Bulletin of the "Hryhoriy Skovoroda State Pedagogical University of Pereyaslav-Khmelnytsky" (Vol. I (61)): Thematic issue "Higher education of Ukraine in the context of integration into the European educational space", 36(1), 337-344.

6. Smolikevych, N.R. (2018). Orhanizatsiino-pedahohichne zabezpechennia adaptatsii inozemnykh studentiv $\mathrm{v}$ universytetakh SSHA [Organizational and pedagogical provision of foreign students' adaptation in US universities]. The author's dissertation abstract for obtaining the scientific degree of candidate of pedagogical sciences : 13.00.01. Lviv : Publishing House of LTD "WUCC".

7. Khrystenko, I.O. (2013). Dosvid pidhotovky inozemnykh studentiv u zarubizhnykh krainakh [Experience of training foreign students in foreign countries]. Theoretical issues of culture, education and upbringing, 47, 74-77.

8. ACE: American Council on Education. (2017). Comprehensive Internationalization: Collaboration and Partnerships. Available at: http://www.acenet.edu/news-room/Pages/Comprehensive-InternationalizationCollaboration-and-Partnerships.aspx (accessed 18 December 2018).

9. Altbach, P.G. \& Knight, J. (2007). The internationalization of higher education: motivations and realities. Journal of Studies in International Education, 11, 3-4, 290-305.

10. Altbach, G.P., Reisberg, L., \& Rumbley, E.L. (2009). Trends in Global Higher Education: Tracking an Academic Revolution. A Report Prepared for the UNESCO 2009 World Conference on Higher Education. France, IV.

11. British Council (2016). Global Gauge. Available at: https://www.britishcouncil.org/education/ihe/knowledgecentre/global-landscape/global-gauge (accessed 21 December 2018).

12. British Council (2014). Outward mobility: student and institution perspectives Available at: https://www.britishcouncil.org/ events/outward-mobility-student-and-institution-perspectives (accessed 11 December 2018).

13. De Wit, H. (2010). Internationalization of Higher Education in Europe and its assessment, trends and issues. NVAO Nederlands-Vlaamse Accreditatieorganisatie.

14. IIE. About the U.S. Department of State Bureau of Educational and Cultural Affairs (2017). Available at: https://www.iie.org/Why-IIE/Announcements/2017-11-13-Open-Doors-Data (accessed 16 July 2018).

15. IIE. International Students in the United States (2017). Open Doors 2017 Executive Summary. Available at: https://www.iie.org/Why-IIE/Announcements/2017-11-13-Open-Doors-2017-Executive-Summary (accessed 28 August 2019).

16. Global Undergraduate Exchange Program (2018). Available at: https://exchanges.state.gov/.../globalundergraduate-exchang

17. Marian at a Glance (2018). Available at: www.marianuniversity.edu (accessed 11 June 2018). 